\title{
MELATIH KETERAPILAN BERBICARA MENGGUNAKAN PERMAINAN "JUST- A-MINUTE" SISWA KELAS VIII SMP NEGERI 11 LHOKSEUMAWE
}

\author{
ROKIM \\ SMP Negeri 11 Lhokseumawe, Aceh \\ edurokim@gmail.com
}

\begin{abstract}
ABSTRAK
Penelitian ini bertujuan untuk mengetahui apa itu game 'Just-A-Minute' serta bagaimana proses pembelajarannya. Selain itu juga untuk mengetahui keefektifan penggunaan game tersebut dalam melatih keterampilan berbicara pada siswa kelas VIII SMP Negeri 11 Lhokseumawe. Lokasi penelitiannya adalah SMP Negeri 11 Lhokseumawe dengan subjek penelitian siswa kelas VIII-6 yang berjumlah 34 siswa, dengan rincian 14 siswa putra dan 20 siswa putrid. Teknik pengumpulan data yang dilakukan adalah dengan cara pengamatan selama proses pemelajaran berlangsung untuk mengamati kualitas proses pembelajaran pada saat diberikan pembelajaran keterampilan berbicara menggunakan game 'Just-A-Minute'. Aspek yang diamati meliputi aspek antusias, partisipasi, kerjasama, dan prakarsa atau produktivitas. Selain itu juga melalui penyebaran angket ke siswa untuk mengetahui respon siswa terhadap penerapan model latihan berbicara menggunakan game 'Just-A-Minute' dalam pembelajaran. Angket tersebut terdiri dai 4 (empat) pertanyaan yang berkaitan dengan ketertarikan terhadap strategi pembelajaran, kemudahan, perbandingan dengan model lain, serta perlu atau tidaknya model pembelajaran tersebut dilanjutkan. Dari hasil pengamatan selama proses pembelajaran kemudian data analisis, diketahui rata-rata kualitas pembelajaran 3,26 berada pada kategori tinggi. Oleh karena itu dapat dinyatakan bahwa pembelajaran menggunakan game 'Just-AMinute' dapat meningkatkan keterampilan berbicara pada siswa kelas VIII - 6 SMP Negeri 11 Lhokseumawe. Sedangkan dari hasil analisis terhadap angket siswa menunjukan bahwa dari 34 siswa, 78,68\% menyatakan sangat setuju jika penggunaan game 'Just-A-Minute' dapat meningkatkan keterampilan berbicara, sangat menyenangkan, mudah serta lebih baik dari model yang lain, dan dilanjutkan $21,32 \%$ menyatakan setuju. Hal ini dapat diartikan bahwa penggunaan game 'Just-A-Minute' efektif dalam melatih keterampilan berbicara siswa kelas VIII-6 SMP Negeri 11 Lhokseumawe.
\end{abstract}

Kata Kunci: keterampilan berbicara, just a-minute.

\section{PENDAHULUAN}

Belajar bahasa adalah menjadi bagian yang teramat penting dalam kehidupan manusia. Pernyataan ini tersirat dalam pernyataan Thomson (1978) yang menyatakan bahwa penggunaan bahasa memungkinkan seseorang mengiterpretasikan pengalaman dan informasi, yaitu belajar dan pengalaman memahami informasi. Beberapa pakar, seperti Berthoff (1978) menyatakan bahwa bahasa Inggris merupakan bahasa internasional yang penting dipelajari dan dikuasai oleh setiap individu, terutama mereka yang ingin memperluas wawasan keilmuan dan terlibat dalam dunia internasional. Seperti diketahui bahwa sejak jaman dahulu banyak sekali buku-buku teks yang ditulis berbahasa Inggris demikian pula dengan sistem informasi yang juga secara mayoritas menggunakan bahasa tersebut. Hal ini menjadi bukti pentingnya kita menguasai bahasa Inggris terutama bahasa lisan (oral language) untuk memperlancar berkomunikasi secara aktif. Dalam Putri \& Elvina (2019: 4) dinyatakan bahwa keterampilan berbicara adalah keterampilan dalam menyampaikan suatu informasi, pesan, ide atau gagasan secara lisan kepada lawan tutur sehingga apa yang disampaikan dapat dipahami dengan baik dan komunikasi dapat berjalan dengan lancar. Berkaitan dengan hal tersebut, maka bahasa Inggris merupakan alat dan metode untuk berkomunikasi secara lisan dan tulis. Pengertian berkomunikasi adalah memahami dan mengungkapkan informasi, pikiran, perasaan serta mengembangkan ilmu pengetahuan, teknolgi, dan budaya dengan menggunakan bahasa tersebut. Kemampuan berkomunikasi dalam pengertian yang utuh adalah kemampuan 
berwacana yakni kemampuan memahami dan/atau menghasilkan teks lisan dan/atau tulis yang direalisasikan dalam empat keterampilan berbahasa, yaitu mendengarkan, berbicara, membaca dan menulis. Kemampuan berbahasa mencakup empat keterampilan pokok, yakni keterampilan menyimak, berbicara, membaca, dan menulis.

Penelitian ini lebih menekankan pada aspek keterampilan berbicara. Keterampilan tersebut perlu dilatih agar siswa dapat berkomunikasi dengan baik dalam menggunakan bahasa Inggris. Menurut Atmazaki (2013:15) pada dasarnya tujuan pembelajaran bahasa adalah membimbing perkembangan bahasa siswa secara berkelanjutan melalui proses mendengarkan, berbicara, membaca dan menulis. Pada akhirnya, tujuan pembelajaran adalah untuk membimbing siswa agar mampu menggunakan bahasa untuk belajar, mengekspresikan ide dengan lancar dan jelas, dan berkomunikasi secara efektif dengan orang lain (belajar menggunakan bahasa, belajar tentang bahasa, dan belajar melalui bahasa). Kemampuan memahami/menghasilkan teks bahasa Inggris sangat penting dimiliki oleh mereka yang sedang mempelajari bahasa Inggris terutama bagi siswa yang berada pada jenjang pendidikan menengah.

Keterampilan berbicara atau speaking dalam bahasa Inggris sering dianggap suatu yang amat sulit bagi sbahagian besar siswa sekolah menengah. Tidak jarang kita jumpai di suatu kelas dimana kebanyakan siswanya mampu menjawab soal - soal bahasa Inggris secara tertulis bahkan mendapatkan nilai sangat memuaskan. Akan tetapi saat diminta mempraktikan kemampuan berbicaranya, hanya sebahagian kecil dari mereka yang mampu melakukannya. Padahal keterampilan berbicara itu sendiri adalah suatu proses produktif yang akan langsung kita terima setelah proses mendengar atau menyimak. Selain itu keterampilan berbicara juga menjadi bahagian yang sangat penting dalam berkomunikasi.

Rendahnya kemampuan siswa dalam keterampilan berbicara ini tentunya disebabkan beberapa hal, antara lain kurangnya latihan yang dilakukan oleh guru serta pola pemberian latihan yang sifatnya relatif monoton, kurang bervariasi bahkan cenderung hanya menjadikan materi tersebut membosankan dan menakutkan. Padahal para ahli sudah merekomendasikan banyak pendekatan atau model - model pembelajaran yang dianggap sangat efektif dalam menunjang kemampuan berbicara siswa dalam pembelajaran. Model - model tersebut kemudian dikemas dalam pola pembelajaran siswa aktif atau Aktive Learning. Silberman (2004) mengatakan bahwa seringkali, belajar aktif akan menjadi bergairah dengan menciptakan tim - tim belajar yang bias belajar bersama, mengerjakan proyek, dan terlibat dalam kegiatan belajar lainnya.

Nuansa kedekatan guru dengan siswa dalam artian yang positif harus ditingkatkan dan dipelihara dengan baik, karena sifat kedekatan ini dapat membantu efektifitas dalam proses pembelajaran. Ini berarti bahwa setiap guru bahasa Inggris agar membangun hubungan yang baik dengan siswa. Guru sangat dituntut untuk mampu memahami konsep materi ajar secara mendalam; mampu menerapkan metode, teknik, dan strategi yang tepat; mampu membuat rencana pembelajaran, mendemonstrasikan dan mengatur kegiatan belajar mengajar; dan mampu memanfaatkan berbagai media pembelajaran, memiliki motivasi dan kemauan yang kuat untuk mengajar. Hal lain yang juga sangat ditekankan adalah bahwa guru dituntut agar mengetahui tingkat perkembangan intelektual dan daya serap siswa, mampu memotivasi, menarik perhatian siswa; dan mampu mengatasi berbagai gangguan guna mengatasi kesulitan belajar siswa. Secara hakikat dapat dikatakan bahwa guru dan siswa adalah mitra dalam menjelajahi dan mencari ilmu pengetahuan.

Berdasarkan uraian di atas, maka dipandang perlu bagi guru dalam meningkatkan kreatifitasnya dalam memilih strategi pembelajaran dalam melatih keterampilan berbicara pada siswa, tidak terpaku pada minimnya waktu yang disediakan serta tuntutan target kurikulum yang tidak tuntas. Akan tetapi harus sejalan dengan tuntutan pembelajaran berbicara yaitu mengungungkapkan dan merespon percakapan transaksional (to get things done) dan interpersonal (bersosialisasi) sederhana secara akurat, lancar dan berterima serta 
mengungkapkan makna dalam monolog pendek sederhana dengan menggunakan ragam bahasa lisan secara akurat, lancar dan berterima untuk berinteraksi dengan lingkungan sekitar.

McDonough, Shaw, \& Masuhara (2013: 171) menyatakan bahwa permainan adalah salah satu cara belajar berbicara bahasa Inggris. Game merupakan salah satu cara pembelajaran yang cukup menarik bagi siswa karena dalam prosesnya siswa tidak dituntut untuk menerima pelajaran dalam kondisi penuh tekanan, melainkan siswa seolah-olah bermain sambil belajar. Dalam penelitian ini, games berbicara yang dipilih harus sesuai dengan kriteria permainan bahasa yang baik dan juga sesuai dengan prinsip-prinsip pengajaran berbicara. Menurut Wright (2005:253) games yang digunakan harus mudah disiapkan, mudah dilakukan di kelas, menarik, mengajarkan keterampilan khusus, dan dilakukan dalam rentang waktu yang sesuai. Constantinescu. (2012:97) juga memberikan kriteria yang sama dengan menambahkan bahwa games harus sesuai dengan subjek dan kurikulum, dan juga sesuai dengan tingkat dan usia siswa. Games juga harus memenuhi kriteria mengajar berbicara yang baik yaitu: memungkinkan latihan, memberikan kesempatan yang sama bagi siswa untuk berbicara, dan membatasi ceramah guru (Nunan, 2003:77).

Tujuan menggunakan game pada pembelajaran adalah sebagai upaya memunculkan nuansa baru dan penuh keriangan dalam pembelajaran. Lebih lanjut lagi Putri \& Elvina (2019: 7) menjelaskan bahwa penerapan games dalam pembelajaran selain menciptakan suasana baru juga mampu meningkatkan keterampilan berbahasa dan juga dapat menumbuhkan karakter pada siswa. Misalnya ketika menggunakan game tertentu maka akan menumbuhkan kreativitas, kekompakan, kebersamaan, kerjasama dan kerukunan antar anggota permainan. Penggunaan game seperti yang penulis angkat dalam karya tulis ini adalah salah satu model yang dapat diterapkan. Menurut Elizabeth Claire (2004) 'Just-A-Minute' adalah jenis permainan atau game yang mudah dilakukan di dalam ruang kelas. Ia menkombinasikan antara kegiatan yang menyenangkan dengan peningkatan keterampilan berkomunikan berbicara yang sangat penting. Penggunaan game 'Just-A-Minute' ini diharapkan mempu meningkatkan kemampuan siswa dalam melatih keterampilan berbicara serta menjadi motivasi bagi siswa untuk meningkatkan keberanian dan rasa percaya diri dalam berkomunikasi secara oral dalam bahasa Inggris. Timbulnya rasa percaya diri itu pun harus melalui suatu proses dan tidak serta merta ketika anak diberikan suatu permainan dalam belajar akan secara otomatis timbul percaya dirinya. Dengan mengemas model pembelajaran itu melalui kegiatan berpasangan atau berkelompok akan memudahkan dalam memotivasi siswa.

Berkenaan dengan judul penulisan ini, maka dalam upaya melatih keterampilan berbicara penggunaan game 'Just-A-Minute' dapat menjadi satu alternatif. Selain mudah disesuaikan dengan bahasa yang lingkupnya berkaitan dengan konteks kehidupan atau lingkungan kehidupan sehari-hari anak, juga disampaikan secara lebih santai dan menyenangkan. Sehingga motivasi anak untuk mulai belajar berbicara dapat lebih tinggi terlebih lagi dalam mendeskripsikan sesuatu benda atau kegiatan yang ada dilingkungan siswa. Claire (2001) menyatakan bahwa 'Just-A-Minute' adalah jenis game bahasa yang medah dalam penjelasan. Ia mengkombinasikan antara kesenangan atau hiburan dengan pengembangan keterampilan berkomunikasi yang penting. Ia memotivasi kejelasan pengucapan atau pronounciation, serta proses mendengar yang seksama.

Dengan memahami teknik tersebut diharapkan dapat bermanfaat sebagai satu strategi alternatif bagi guru Bahasa Inggris SMP untuk melatih keterampilan berbicara siswa. Karena bagaimanapun guru memang harus mencoba mengembangkan berbagai strategi yang dianggap baik untuk kemajuan peserta didiknya. Husein Shahatah (2004) mengatakan selama tidak bertentangan dengan syariat, seorang manusia (guru) mempunyai kebebasan dalam mengembangkan ide dan inisiatif yang bermanfaat bagi ilmu pengetahuan dan sarana - sarana pendukungnya. Selain itu juga diharapkan dapat menjadi bahan acuan atau perbandingan untuk mengembangkan strategi pembelajaran berbicara lainnya yang lebih efektif dan lebih bersifat inofatif pada siswa SMP. 


\section{METODE PENELITIAN}

Penelitian ini dilakukan di SMP Negeri 11 Lhokseumawe Provinsi Aceh. Sekolah ini terletak di Ujung Timur Kota Lhokseumawe yang berbatasan langsung dengan Kabupaten Aceh Utara. Sekolah ini mempunyai 18 Rombongan Belajar (Rombel), yang terdiri 6 (enam) Rombel kelas VII, 6 (enam) Rombel Kelas VIII dan 6 (enam) Rombel kelas IX. Selain lokasinya berada tepat di tepi jalan negara Banda Aceh - Medan, sekolah ini juga merupakan salah satu sekolah yang pernah menyandang predikat Sekolah Standar Nasional (SSN) sejak tahun pelajaran 2010/2011, hingga kemudian pemerintah meniadakan status Rintisan Sekolah Berstandar Internasional (RSBI) maupun SSN pada setiap sekolah.

Subjek penelitian ini adalah seluruh siswa kelas VIII-6 SMP Negeri 11 Lhokseumawe Tahun Pelajaran 2019/2020. Subjek penelitian tersebut berjumlah 34 orang dengan sebaran laki-laki berjumlah 14 siswa, dan perempuan sebanyak 20 siswa. Pengumpulan data dalam penelitian ini dilakukan melaui beberapa teknik, antara lain:

1. Format pengamatan, Digunakan untuk mengamati kualitas proses pembelajaran pada saat diberikan pembelajaran keterampilan berbicara menggunakan game 'Just-AMinute’. Asfek yang diamati meliputi asfek antusias, partisipasi, kerjasama, dan prakarsa atau produktivitas.

2. Digunakan untuk mengetahui respon siswa terhadap penerapan model latihan berbicara menggunakan game 'Just-A-Minute' dalam pembelajaran. Angket tersebut terdiri dai 4 (empat) pertanyaan yang berkaitan dengan ketertarikan terhadap strategi pembelajaran, kemudahan, perbandingan dengan model lain, serta perlu atau tidaknya model pembelajaran tersebut dilanjutkan.

Adapun teknik análisis data pada penelitian ini dilakukan dengan 2 cara, yaitu

1. Menganalisis kualitas proses pembelajaran, Data pembelajaran kualitas proses pembelajaran dianalisis menggunakan teknik persentase dengan rumus:

Keterangan:

$$
P=\frac{f}{N} \times 100 \%
$$

P: Persentase,

f: frekuensi,

N: Jumlah Responden (Sumarmo, 1989)

2. Menganalisis respon siswa, Respon yang diberikan siswa terhadap teknik 'Exelco' yang dijaring melalui angket dianalisis persentasenya dengan menggunakan rumus:

$$
P=\frac{f}{N} \times 100 \%
$$

Keterangan:

P: Persentase,

f: frekuensi,

N: Jumlah Responden (Sumarmo, 1989)

\section{HASIL DAN PEMBAHASAN}

Pemanfaatan permainan / game 'Just-A-Minute' dalam pembelajaran siswa kelas VIII6 SMP Negeri 11 Lhokseumawe dalam pembelajaran berbicara Bahasa Inggris telah dikembangkan pada semester genap tahun pelajaran 2019/2020, yang dapat diuraikan sebagai berikut.

Kualitas Pembelajaran, pada waktu proses pembelajaran, diamati pula kualitas pembelajaran. Adapun aspek yang dinilai terhadap siswa tersebut adalah sikap antusias, 
partisipasi dalam kegiatan, kerjasama dalam kelompok serta hasil kerja atau prakarsa sebagaimana diuraikan dalan tebel berikut:

Tabel 1. Kualitas Pembelajaran

\begin{tabular}{lccc}
\hline \multirow{2}{*}{ ASPEK } & \multicolumn{2}{c}{ SKOR } & \multirow{2}{*}{ KATEGORI } \\
\cline { 2 - 3 } & $\sum$ & RATA-RATA & \\
\hline Antusias & 101 & 3,26 & Tinggi \\
Partisipasi & 104 & 3,35 & Tinggi \\
Kerjasama & 97 & 3,13 & Tinggi \\
Prakarsa / Hsil & 102 & 3,29 & Tinggi \\
Kerja & & & \\
\hline \multicolumn{1}{c}{ JUMLAH } & 404 & 13,03 & Tinggi \\
\hline RATA-RATA & & 3,26 & \\
\hline
\end{tabular}

Dari hasil analisis data di atasdiketahui rata-rata kualitas pembelajaran 3,26 berada pada kategori tinggi. Oleh karena itu dapat dinyatakan bahwa pembelajaran menggunakan game 'Just-A-Minute' dapat meningkatkan keterampilan berbicara pada siswa kelas VIII - 6 SMP Negeri 11 Lhokseumawe.

Respon Siswa, Untuk lebih menguatkan asumsi terhadap keefektifan penggunaan game 'Just A Minute; dalam melatih keterampilan berbicara bahasa Inggris dimintai respon siswa mengenai model tersebut melaui angket yang berkaitan dengan beberapa aspek seperti tertuang dalam table berikut:

Tabel 2. Respon Siswa Terhadap Penggunaan Game 'Just-A-Minute'

\begin{tabular}{clcccccc}
\hline NO & PERNYATAAN & SS & S & TP & TS & STS & JLH \\
\hline 1. & Menyenangkan & 25 & 9 & 0 & 0 & 0 & 34 \\
2. & Mudah & 20 & 14 & 0 & 0 & 0 & 34 \\
3. & Lebih Baik Dari & & & & & & \\
& Cara yang Lain & 28 & 6 & 0 & 0 & 0 & 34 \\
4. & Dilanjutkan & 34 & 0 & 0 & 0 & 0 & 34 \\
\hline & JUMLAH & $\mathbf{1 0 7}$ & $\mathbf{2 9}$ & $\mathbf{0}$ & $\mathbf{0}$ & $\mathbf{0}$ & $\mathbf{1 3 6}$ \\
\hline & RATA-RATA & $\mathbf{7 8 , 6 8}$ & $\mathbf{2 1 , 3 2}$ & & & & $\mathbf{1 0 0}$
\end{tabular}

Tabel di atas menunjukan bahwa dari 34 siswa, 78,68\% menyatakan sangat setuju jika penggunaan game 'Just-A-Minute' dapat meningkatkan keterampilan berbicara, sangat menyenangkan mudan serta lebih baik dari model yang lain, dan dilanjutkan 21,32\% menyatakan setuju. Berdasarkan tabel tersebut juga terlihat bahwa tidak seorangpun menyatakan tidak setuju atau tidak ada pendapat, apalagi yang sangat tidak setuju. Oleh karena itu dapat disimpulkan bahwa penggunaan game 'Just-A-Minute' dalam melatih keterampilan berbicara bahasa Inggris siswa mendapat tanggapan atau respon yang sangat positif dari siswa kelas VIII-6 SMP Negeri 11 Lhokseumawe.

\section{Pembahasan}

Hasil analisis data sebagaimana diuraikan di atas menjelaskan bahwa hasil belajar siswa kelas VIII-6 SMP Negeri 11 Lhokseumawe setelah menggunagan game 'Just-A-Minute' lebih tinggi jika dibandingkan dengan hasil belajar sebelum menggunakan game tersebut pada taraf signifikasi $\alpha 0,05$. Jika mengacu pada criteria keefektifan yang telah ditetapkan dan ditelaah, dianalisis sesuai teknik analisis, maka dinyatakan penggunaan game 'Just-A-Minute' efektif dalam melatih keterampilan berbicara bahasa Inggris pada siswa kelas VIII-6 SMP Negeri 11 Lhokseumawe.

Kualitas pembelajaran menunjukan bahwa siswa yang telah diajarkan praktik berbicara menggunakan game 'Just-A-Minute' rata - rata 3,26 dikategorikan tinggi. Karena itu dapat dikatakan bahwa penggunaan game 'Just-A-Minute' dapat meningkatkan kualitas proses pembelajaran berbicara bahasa Inggris siswa kelas VIII-6 SMP Negeri 11 Lhokseumawe. 
Selanjutnya respon siswa terhadap penggunaan game 'Just-A-Minute' dalam melatih keteranmpilan berbicara siswa kelas VIII-6 SMP Negeri 11 Lhokseumawe menunjukan 78,68\% menyatakan sangat setuju, $21,32 \%$ setuju dan $0 \%$ yang menyatakan tidak ada pendapat, tidak setuju, apalagi yang sangat tidak setuju dari aspek kemenarikan, kemudahan, perbandingan dengan teknik atau model yang lain serta kelanjutan penggunaan game 'Just-A-Minute'. Oleh karena itu maka penggunaan game 'Just-A-Minute' dalam melatih keterampilan berbicara bahasa inggris mendapat respon yang sangat positif dari siswa kelas VIII-6 SMP Negeri 11 Lhokseumawe sehingga dinyatakan penggunaannya efektif.

\section{KESIMPULAN}

Berdasarkan dari uraian di tas dapat kiranya disimpulkan bahwa salah satu upaya untuk meningkatkan keterampilan berbicara yang efektif adalah menggunakan game 'Just-A-Minute'. Hal ini didasarkan pada bukti bahwa setelah diterapkan dalam pembelajaran, keterampilan berbicara siswa lebih meningkat yang terpantau dari uji coba yang efektif, kualitas pembelajaran yang boleh dikatakan tinggi serta respon siswa yang sangat positif.

\section{DAFTAR PUSTAKA}

Atmazaki. (2013). “Implementasi Kurikulum 2013 Mata Pelajaran Bahasa Indonesia: Pola Pikir, Pendekatan Ilmiah, Teks (Genre), dan PenilaianOtentik". Proceeding on International Seminar on Languange and Art. Padang: Universitas Negeri Padang

Berthoff, A, E. (1978). Rechards on Rethoric I.A. Rechads Selected Essays. Oxford: Oxford University Press.

Claire, Elizabeth. (2001). Just-A-Minute (The Game That Has Everyone Talking. New York: Eardly Publication.

Constantinescu, R. S. (2012). Learning by playing: Using computer games in teaching English grammar to high school students. Paper presented at The 8th International Scientific Conference e-Learning and software for Education, Bucharest.

McDonough, J., Shaw, C., \& Masuhara, H. (2013). Material and Methods in ELT: Teacher's Guide. Southern Gate: Blackwell Publishing.

Nunan, D. (2003). Practical English Language Teaching. New York: McGraw-Hill Company inc.

Putri, Delia., \& Elvina. (2019). Keterampilan Berbahasa di Sekolah Dasar; Melalui Metode Game's. Jakarta: CV. Qiara Media.

Silberman, L, Martin. (2004). Active Learning: 101 Cara Belajar Siswa Aktif. Bandung: penerbit Nusamedia.

Thomson, J. (1978). Language in the Classroom. Occasional Paper. Applied linguistics Association of Australia.

Wright, A., Betteridge, D., \& Buckby, M. (2005). Games for language learning (3rd ed.). New York: Cambridge University Press. 